\title{
Becoming Independent: Political participation and youth transitions in the Scottish Referendum
}

\begin{abstract}
Sociological debates on youth engagement with electoral politics play out against a backdrop of supposed 'decline' in civic participation (e.g. Putnam 2000, Norris, 2011), in turn contextualized by theories of individualization in 'late' or 'reflexive' modernity (Beck, Giddens). However, the enfranchisement of 16 and 17 year olds in the 2014 Scottish Independence Referendum catalysed remarkably high levels of voter turnout among this youngest group, and was accompanied by apparently on-going political engagement. We explored this engagement among a strategic sample of young 'Yes' voters, in the immediate aftermath of this exceptional political event. Analysis of qualitative interview data generated an unanticipated finding; that interviewees narrated their political engagement biographically, articulated their referendum participation reflexively, and located their new political ideas, allegiances, and actions in the context of their own transitions to 'independent' adulthood. This inspired us to re-think young people's political engagement in relation to youth transitions. Doing so enables a synthesis of divergent strands in the sociology of youth, and offers new insights into the combinations of 'personal' agentic and 'political' structural factors involved in young people's politicisation.
\end{abstract}

Key words Young People, Political Participation, Youth Transitions, Scottish Independence 


\section{Introduction}

On $18^{\text {th }}$ September 2014 , by a narrow $55 \%$ majority, the people of Scotland voted against becoming independent from the United Kingdom. The result, however, tells only a small part of the larger sociological story that frames this paper. Firstly, the referendum saw unprecedented levels of electoral registration (97\%) and voter turnout (85\%). The referendum drew people disengaged from electoral politics into debate and action. Secondly, despite perhaps because of - the result, there were post-poll surges in pro-Yes party membership, particularly the Scottish National Party (SNP). Thirdly, the referendum extended the franchise to 16 and 17 year olds in Scotland. This was accompanied by a discourse re-framing 'defeat' at the polls on $18^{\text {th }}$ September into a 'victory' of participation and engagement with electoral politics.

Given recurrent claims of youth disengagement (Russell et al 2002; Kisby \& Sloam 2009), the decision to enable 16 and 17 year olds to vote raised serious concerns, yet was subsequently heralded as a success for youth political engagement (Eichhorn et al 2014, 2015). Contrary to expectations, 16 and 17 year olds voted 'in greater numbers than 18-24 year olds and at levels close to the overall population' (Eichhorn et al 2015: 1). The voting age in Scotland - for Scottish Parliament and local authority elections, though not for UK General Elections or UKwide referendums such as the vote on EU membership in June 2016 - was permanently lowered in June 2015.

In this paper we draw on in-depth interviews with a small strategic sample of young 'Yes' voters conducted in March-April 2015, in order to understand the peculiar participation dynamics of this event from the perspective of young people who voted for the first time, and subsequently continued to be politically engaged despite their initial disappointment with the 
result. Whilst literature highlighting youth disengagement might lead us to expect otherwise, participants described new and renewed interests in a range of political issues and continued political action. Our findings join those that challenge claims of youth disengagement (Henn et al 2002; Henn \& Foard 2014).

Moreover, this article is primarily concerned with an unexpected aspect of our findings; that interviewees narrated their becoming politically engaged biographically, articulated their referendum participation reflexively, and understood their new political ideas, allegiances, and actions as increasingly independent from their parents, teachers, and peer-groups. For these young people, political participation was a component of their transitions to adulthood, developing a sense of their adult self, learning new competencies, maturity, and carving out a kind of independence for themselves; leaving school and planning for a future of employment and/or further study. We therefore rethink young people's political engagement in relation to youth transitions.

We begin with an overview of local and national referendum politics, followed by a review of sociological literatures on youth political participation and youth transitions, noting that both are concerned with shifts in participation and transitions. We then offer a summary of the scope of our exploratory, qualitative methods. Three data analysis sections illustrate how:

1) Participants narrated moving from 'political disengagement' (which for some included being interested but not active) to active engagement;

2) The importance of critical moments and significant others in this shift;

3) Interviewees saw themselves as moving away from the influence of significant others and developing their own more autonomous political ideas, allegiances, and actions. 
Moreover, participants spoke of developing new skills, and drew on their referendum experiences to make sense of leaving school and transitioning to further study and/or employment, as well as to understand disappointments and opportunities in their life-courses. In the wake of the referendum result, participants (re)connected to political institutions and saw their emergent adult selves as politically engaged.

\section{Scotland Decides: Local and National Political Context}

In the 2011 Scottish Parliament elections, the Scottish National Party (SNP) secured an unprecedented majority and pressed ahead with plans to hold a referendum on Scotland's independence. Agreement was reached with the UK Government in 2012, such that Scottish voters would face the choice of becoming an independent country or remaining part of the United Kingdom in September 2014. The pro-independence 'Yes Scotland' campaign saw an alliance of the SNP, Scottish Greens and the Scottish Socialist Party (SSP), with Conservatives, Labour and Liberal Democrats campaigning for a 'No' vote under the pro-union 'Better Together' alliance.

The campaigns ultimately galvanised the electorate, generating high levels of political interest. As one of our respondents put it "Everyone was talking about politics for the first time that I can really remember... it was good to be able to speak about politics, completely freely." (Russell $\left.{ }^{1}\right)$

As this suggests, engagement was not limited to 'official' party campaigns, and went beyond traditional political institutions. Grassroots activism appeared to thrive, and pro-independence activity expanded as the poll approached. Whilst media attention focussed on the official Yes

\footnotetext{
1 Note that all names are pseudonyms.
} 
Scotland campaign, autonomous organizations such as the Radical Independence Campaign, Women for Independence, National Collective, and youth groups (e.g. Generation Yes) were adept at using social media to give the impression that the Yes side offered an alternative to 'business as usual' politics in grassroots mobilisation. In the words of another interviewee:

It was a really positive experience... to see like van workers on the street who you'd never dream would be talking about politics, and you could hear them debating... it was really positive for me to see that, I would like to see that more often in politics, I think people get disenfranchised with it... it seems to me as well that it's for a certain elite, for us people down at the bottom, nothing ever really changes... but I think people recognized that this was quite a big thing, that this was bigger than party politics... (Brian)

Alongside this, and after the 'No' result, pro-Yes parties reported remarkable membership growth. Less than a week after the referendum SNP membership surged from 25,642 to over 42,000, with the Scottish Greens claiming 'thousands' of new entrants (BBC, 2014: n/p). A year later, in October 2015, the Scottish Greens had over 9,000 members (up from 1,700 prereferendum) (Kennouche, 2015). The SNP claim that their membership increases were part of the 'incredible legacy of democratic engagement from the referendum' (Duncanson, 2015), and these have been sustained over time; by June 2016 SNP membership sat at 120,000 (Keen and Audickas, 2016: 12). The referendum appears to have involved a combination of 'old' and 'new' forms of engagement, within and beyond party politics. For our interviewees, the referendum acted as a catalyst, a critical moment in a process that was both intimately personal and much broader than voting on the day itself; the transition to becoming 'independent', politically engaged young adults. 


\section{Youth Politics, Youth Transitions}

Initial scepticism about the enfranchisement of 16 and 17 year olds in the referendum, according to Eichhorn et al., was based on assumptions that 'Young people are less interested in politics', 'will vote exactly like their parents', and 'will be prone to copy ideas they are given in schools' (2014: 1). This echoes long-standing research suggesting that young people are especially disengaged from electoral politics (Russell et al. 2002; Power Commission 2006; Sloam 2007; Henn et al 2002; Henn \& Foard 2014; Furlong \& Cartmel 2012; Manning \& Edwards 2014) and that children receive a political socialisation in the context of their families (Coles 1986). The underlying assumption that 16 and 17 year olds do not have meaningful political agency relies on conceptions of them as somewhat dependent on families and educational institutions.

However, the Electoral Commission reports that $75 \%$ of 16 and 17 year olds surveyed claimed to have voted (TEC, 2014: 1), and Eichhorn et al.'s survey work found that:

Under-18 year olds showed similar average levels of political interest to adults, were not simply following their parents' lead (over $40 \%$ held a different view on the referendum question than a parent who was also interviewed) and were engaging with a wide range of diverse media and information sources (2015:1)

Such findings offer a stark contrast to portrayals of 'the average young person' who 'does not vote, does not participate in conventional politics and does not feel represented by politicians and political parties' (Sloam, 2007: 562), and buck the trend of low youth electoral turnout. Henn \& Foard (2014: 361) reported that less than 40\% of the UK's 18-24 year olds voted in 
the General Elections of 2001 and 2005. This contrasted with a turnout of over $70 \%$ amongst those aged 65+ in 2001 (Russell et al. 2002: 6). More recently, British Social Attitudes found that around half of those under 35 described their general interest in politics as 'not very much' or 'none', compared to just one-third of those aged $65+^{2}$.

Low election turnout (Hay, 2007), falling membership of political parties and labour unions (Stoker, 2006), and claims of decreased engagement in social movements (Putnam, 2000) are often interpreted as symptomatic of a 'deepening crisis of democracy' (Russell et al. 2002: 7). Here formal politics seem distant and impermeable, with a 'culture of non-participation by young people' (Matthews et al 1999: 135) who perceive politics as unresponsive to their needs (Hansard Society 2009; Manning \& Edwards 2014). Young people are disillusioned with the political process to the extent that the word " "politics" itself has negative connotations' (Sloam 2007: 556). There is 'widespread agreement in mainstream participation studies that social capital and civic engagement in Western democracies are in steady and continuous decline' (Bang, 2009: 117).

However, sociological research challenges claims about 'politically apathetic' and 'disengaged' youth (Power Commission 2006; Sloam 2007; Henn et al 2002; Marsh et al 2007), and raises critical questions about how researchers define 'politics'. Dissatisfaction with and disconnection from formal politics need not mean disengagement and disinterest in political issues more generally (Kisby \& Sloam 2009; Henn \& Foard 2014). As Marsh et al (2007), Norris (2011) and Eichhorn et al (2014) argue, young people may be disengaged from traditional political institutions, but engaged in political issues and causes. For instance, Marsh et al (2007) chart new modes of social and political engagement amongst young people that

\footnotetext{
${ }^{2}$ Authors' own analysis of British Social Attitudes, 2013.
} 
are more issue-focused and relevant to their lives. As Bang suggests, apparently 'apathetic' young people 'may turn out to be the most active in more informal and ad hoc governance networks and practices' (2009: 128).

From this perspective young people are politically active, but a narrow focus on formal politics in mainstream participation studies is insensitive to new forms of engagement (Marsh and Akram, 2015: 523). With a broader definition of 'politics', we can see that a decline in traditional modes of participation has been accompanied by a rise in alternative forms, 'on the boundaries between the social, proto-political and political' (Marsh and Akram 2015: 525). Such politics has 'more fluid boundaries, looser networked coalitions, and decentralized organizational structures' (Norris 2007: 638), and is 'not solely a matter of being either for or against "the system" but rather, can vacillate between these two positions, or strategically combine them' (Bang 2009: 131).

In sum, this literature suggests that 'the political system and the established parties and politicians that dominate it, are together failing to provide the stimuli necessary to encourage young people to engage with formal politics' (Henn \& Foard 2014: 373). 'The response to this problem', as the Power Commission put it, 'should be about a rethinking of the way we do politics in Britain' (2006: 15). Sloam (2007: 563) also notes: 'the most effective way of empowering young people, and making them see the efficacy of their participation, must be through mobilisation at the local level.'

Scotland's referendum was different from 'normal politics' in that it offered a stark choice between 'yes' and 'no' in a context where every vote was of equal weight. Some factions of the Yes campaign also offered the chance of changing the UK political system, especially 
relevant in terms of young people as "“engaged sceptics" ... interested in political affairs but distrustful of those who are elected to positions of power' (Henn et al 2002: 187). At the same time the referendum seemed to galvanise formal politics as 'the number of under-18 year olds who did not feel close to any political party declined' over the course of the campaign (Eichhorn et al. 2015: 1). The referendum potentially spanned that "porous boundary... between traditional and new forms of political participation' (Marsh and Akram 2015: 529).

Central to arguments about shifting forms of participation are 'late' modern theories of reflexive, risk-taking individuals, whose political affiliations are less structured by 'preconstituted interests/organizations, such as class and political party affiliation' (Marsh and Akram 2015: 524-5). Fluidity of identity, in a context of supposed decreasing fixity of structural determinants, means that, for reflexive individuals, deliberately choosing not to engage in conventional 'big' politics allows for engagement where 'the personal is the political' and increasing emphasis on politics as 'lived experience' (Bang, 2009: Marsh and Akram, 2015). Rubin found that young people develop civic identities as reactions to everyday personal experiences (2007: 7), and Ballard shows how young people can be 'motivated toward civic involvement by personal goals or self-interests' (2014: 13). Given these trends, alongside Russell et al.'s (2002: 7) argument that 'a person's first electoral experience might colour their entire career as a voter', we now turn to youth transitions.

Youth transitions research shares a focus on 'late' modernity with participation studies, in that 'traditional youth transitions' are fracturing, and becoming 'substantially different from those of their parents' generation' (MacDonald 1998: 163). Increasing emphasis is placed on agency and reflexivity. Jones (1996) argues for a more malleable concept of transition, as movement between dependence and independence, in order to understand individual agency, as do Thomson and Holland (2002) on young people 'imagining' and 'inventing' adulthoods. These 
trends draw on Beck's (1992) work on individualization, and Giddens (1984; 1991) on 'structuration' and Barry (2010: 123) characterizes transitions research as 'swinging between structuralism and back towards a "new freedom" of individualised lifestyles and reflexive construction of one's own biography'. A preoccupation with such dichotomies can come at the expense of, for instance, explorations of citizenship (Barry, 2010: 124).

Henderson et al. (2004: 218) advocate for 'a more subjective approach to citizenship' among young people whereby 'participation is not deferred to some distant future in which economic independence is achieved' but is rather 'understood as constantly constructed in the present'. They concentrate on the "ways that young people sought out opportunities for competence and recognition in different fields' (ibid). Thomson et al. (2002: 335) similarly focus on the interactions between 'choice, chance and opportunity' to explore critical moments - events that young people themselves see as consequential in their lives - and as 'having particular biographical significance'. Holland and Thomson (2009: 451) explore the relationship between critical biographical moments and ideas of fatefulness, drawing on Gidden's (1991) notion of 'fateful moments' in which people are confronted by significant changes and choices requiring reflexive engagement.

Similarly significant others are central in supporting young people's transitions to adulthood (Wyn and Dwyer 1999), and demonstrate the interrelationship between formal support services, and broader, informal social networks and relationships, that can include, but are not limited to, family members, peer groups, and intimate partners. Again this parallels participation literature, including those that emphasize how the provision of 'formal' opportunities for civic and/or political engagement alone is insufficient to secure young people's participation (Ballard 2014). While some studies highlight the importance of 'formal' 
citizenship education classes for increasing young people's political engagement (Cunningham and Lavalette 2004: 266), Eichhorn et al. (2015) stress the importance of informal political learning within peer groups and social networks.

Stephen and Squires (2003: 145) argue for expanding the concept and application of 'transition' in youth studies, and we contribute to this project by using the concept as an analytical lens, to attend to young people's own reflexive and biographical understandings of how they became politically engaged in the 2014 Scottish Independence Referendum. In this way we combine attention to youth transitions with youth participation in order to 'bridge the analytical divide' (MacDonald and Shildrick, 2007: 339) between sociological traditions in youth research.

\section{Methods}

We conducted ten in-depth, qualitative, semi-structured interviews in March-April 2015. Participants were aged between 16-20 at the time of interview, all voted 'Yes' to independence in the referendum, and for all but one this was the first time they had voted. ${ }^{3}$ We recruited participants from three Scottish cities via an online call circulated on social networking sites and through youth work organizations and political associations. Participants were drawn from locations chosen for their 'Yes city' status (Dundee and Glasgow) and majority 'No' vote (Edinburgh) respectively. Interviews lasted 60-90 minutes, all but one taking place face to face,

\begin{tabular}{|l|l|l|}
\hline NAME & AGE & PARLIAMENTARY \\
& & CONSTITUENCY \\
\hline
\end{tabular}

\footnotetext{
3 'James' had voted (for the first time) in the 2014 European elections.
} 


\begin{tabular}{|c|c|c|}
\hline Russell & 16 & Dundee West \\
\hline Sandra & 16 & Dundee West \\
\hline Anne & 17 & Edinburgh North \& Leith \\
\hline Tom & 17 & Edinburgh South West \\
\hline Gregg & 18 & Edinburgh West \\
\hline Mike & 18 & East Renfrewshire \\
\hline Pamela & 18 & Edinburgh West \\
\hline Brian & 19 & Edinburgh North \& Leith \\
\hline Fiona & 19 & Dundee East \\
\hline James $^{4}$ & 20 & Glasgow North \\
\hline
\end{tabular}

The decision to focus exclusively on young 'Yes' voters is driven by the referendum result. It might be expected that an initial 'unsuccessful' encounter with formal politics would result in a retreat from participation to disengagement. However, Eichhorn et al's survey results suggest that engagement effects were initially sustained, with $65 \%$ of Scottish $18-19$ year olds responding that they were certain to vote in the 2015 General Election, compared with only $34 \%$ of English respondents of the same age (2015: 2); the enfranchisement of 16 and 17 year olds likely has consequences for youth engagement that transcend the specificities of the referendum (Eichhorn et al. 2015: 1-3). We therefore prioritize the experiences of a small sample of 'Yes' voters, exploring their understandings of their own referendum participation.

\footnotetext{
${ }^{4}$ This interview was conducted via video-call.
} 
Mainstream participation studies often use a narrow, exclusively formal definition of 'politics' in which 'there is little engagement with how young people themselves conceive of the political' and 'it is frequently assumed that if individuals do not engage in the activities that researchers take to represent political participation, they are politically apathetic' (Marsh et al 2007: 18-19). By contrast, we designed interview schedules that included questions about how participants defined 'the political', and asked more widely what interviewees were passionate about; local, national or global issues that mattered to them; groups that they belonged to; and their hobbies and activities. It is striking therefore, that we did discover an apparent connection to formal electoral politics, as well as involvement in a much broader range of activities. Whilst youth transitions were not a deliberate focus, we were struck by the high frequency of participants' reflections on their sense of emergent adulthood as they narrated becoming politically active, and during analysis this theme developed as one contribution to understanding politics as lived experience and from young people's own perspectives (Bang, 2009: 128-9).

Our strategic focus on young, first-time pro-independence voters, whose self-selection into the study likely indicates unusually high degrees of political interest, very much informs the character of our findings and limits their generalizability. While further research is required amongst those that voted No, those who did not vote in the referendum, and young people who voted for the first time in other electoral events, our intention is to present an exploratory case in situating political engagement in relation to young people's own understandings of their emergent adulthoods.

\section{$\underline{\text { Data and Analysis }}$}




\section{From (dis)interest to active involvement}

Although all respondents voted in the referendum, in their accounts they were previously rather similar to the 'disengaged' youth described in the literature. While voting Yes, and a member of the SNP at the time of her interview Anne described how:

They'd [my family] been No straight from the start, but I was a No at the start, I wasn't actually gonna vote at the start of it, 'cause I wasn't really interested in politics before the referendum.

(Anne)

Anne describes herself before the referendum as the stereotypically disengaged young person, 'voting in exactly the same way as their parents' (Eichhorn et al 2014). Political interest was new for others too:

I think people were quite surprised, there'd be some people who would remember me from sort of third year or fourth year [of high school] and they were kinda surprised to see me all interested in politics.

(Tom)

[In the future] I will always make sure that I vote and that I keep up to date with it and all [...] I was totally, in the blank when it came to it before, I wouldn't know much about it, but I do now.

(Sandra) 
While describing themselves as previously disinterested and uninformed, continued political engagement was palpable for respondents: Anne was standing for election to the Scottish Youth Parliament [SYP]. Tom was elected to an uncontested seat in the SYP, and Sandra spoke of her commitment to voting for the 'rest of my life'.

Others described a long-standing interest in Scottish politics, but saw themselves as inactive prior to the referendum:

I've always been politically aware, but I've not always been politically active, I think that's what the referendum did to a lot of people, got people who were interested to be active.

(Mike)

I'd been seeing this whole sort of build up to the referendum for the whole period, and I'd been doing nothing to do with it at all... I didn't know how to get started, but I wanted to...

(James)

James gave a detailed account of this shift, ultimately canvassing 'every day' with the official Yes campaign in Glasgow. Anne described 'literally always talking about the referendum' at school, and this kind of enthusiasm, which went beyond official channels, led to a greater sense of awareness and knowledge about politics among our sample:

I think yeah, it's definitely a legacy of the referendum and it's made a lot of people I know, very, extremely aware, a lot more aware than before and a lot more interested, and 
I feel like a lot of that's based in people feeling like they have a stake in the change, whereas that wasn't really the case before.

(Gregg).

This articulates a sense of accessibility and relevancy, and Gregg described feeling an 'ownership of Scottish politics'. We see the referendum's unique character in combinations of 'traditional' and 'new' forms of engagement:

Before the referendum nobody knew about anything that was going on, they were saying the CND [Campaign for Nuclear Disarmament] rally they had last year, hardly anyone turned up to it, but this year there was four thousand people that were there, it's just things like that you don't know about then, but now everyone knows about everything that's going on.

(Fiona)

For Fiona, who got active in local pro-independence groups after the vote, the referendum catalysed her involvement in a range of issues, including anti-Trident activism, homelessness, anti-austerity, and support for local businesses. Here we see 'new' forms in combination with 'old', 'formal' modes of participation. While six of our interviewees had joined political parties as a consequence of the referendum, for Tom, the rush to join pro-Yes parties - including his own SNP membership - was an attempt to halt any return to political 'business as usual'. When asked what she had learned from the referendum, Pamela - who did not join a party - identified a new sense of 'making things happen': 
I have actually learned that like if you want something to happen, you cannae sit and moan about it, you have to go out and do it and make it happen.

(Pamela)

'Making it happen' summarizes the becoming engaged theme. While respondents presented themselves as previously disinterested and/or inactive, they were inspired to vote and campaign in the referendum, and moreover, these experiences galvanized ongoing forms of political action. For some this manifested in joining a political party, including the SNP (Anne, Fiona, Tom, James), Scottish Greens (Russell), or Scottish Socialists (Mike). For others it translated into rejection of party politics and commitment to 'grassroots activism' (Brian), or - as with Fiona - in combinations of both formal and informal engagement. Respondents understood themselves as becoming engaged via the referendum, but it wasn't only the referendum that catalyzed this activity.

\section{Critical Moments and Significant Others}

Whilst the referendum provided an opportunity for participation, the mere existence of opportunities is no guarantee that young people will take them up (Ballard 2014). James describes the role of significant others from his extended family, and the critical moment of happening across a 'Yes' campaign shop, as central to his shift from interest to action:

In 2007 my cousin was in Young Scots for Independence, and he came to visit us for a bit and brought all of his SNP stickers, 'independence nothing less' was the slogan, that really fired my imagination, it was really quite intoxicating [...] I asked him if he could put me in the right direction [...] but apart from that, I'd done nothing at all with the 
campaign, until one day, in August 2014, I was walking to Tesco, past one of the Yes shops, $[\ldots]$ and there was one of the SNP councillors sitting outside, and he asked me if I was interested... and I was just like 'oh aye I'm voting Yes', and I told him that I'd been wanting to get involved in the campaigning for a while, and he just said 'oh come in, and we'll get you started' and [...] I started the same day, I did a leaflet run and I did some canvassing and then it was pretty much every day for the next four weeks. (James)

For James this chance encounter was the critical moment at which his desire to 'get involved', transformed into substantive political action. For Anne, significant others catalysed a change in her views, identifying her pro-Yes ex-boyfriend, who encouraged her to research referendum issues and decide for herself, and her Media Studies teacher:

It was actually my Media teacher ... I walked past his class, and he bought me in, and he was like 'have you ever thought about joining the Scottish Youth Parliament?' and I was like 'never heard of it honestly' and he started showing me all this stuff online and he was like 'I think you'd be really good for it, you should really go for this'... and that sort of sparked me, like I should do something.

(Anne)

James' and Anne's examples point to the importance of family members, intimate partners and school teachers in fostering political activity. Within this milieu, school was crucial to developing political engagement. Brian attributed his 'staying interested in politics' to his Modern Studies teacher, and Fiona likewise described her Modern Studies tutor as a 'true SNP 
fan... the reason I vote SNP today, is because of him'. Learning and debate was not by any means confined to the classroom:

I was in Fifth Year at the time, the Sixth Years at the time were all quite political, a lot of them all did Advanced Higher Modern Studies, so they all knew what they were talking about, and I was in the common room a lot of the time with them, and just hearing them all talk about it, and then I started getting interested and going to research it. (Anne)

I think I learned just as much about it as anyone else did you know, 'cause it just created a thing where everyone was talking, where you know everyone was interested and it was a lot more talk than would usually happen, that kind of thing, so I think I kind of clarified my own views, I mean not consciously but just by kind of listening and reading and also talking I kind of worked out what I thought as well.

(Russell)

Sandra also reported how 'hearing what other young people had to say about it was actually really quite informative'. Participants' emphasis on on-going learning is striking: 'I learned along the way, just kept on learning as you went along, just picked up things here and there, I still am learning as well' (Mike). Participants described themselves not as dependent on significant others for their nascent political attitudes, but as inspired and supported to develop their own views, in a 'reflexive project of identity' (Giddens in Thompson et al. 2002: 338). Our participants did not see themselves as uncritically copying what they were told, but reflected on how their own understanding had developed, in some cases from quite 'naïve' beginnings: 
When I first moved to Scotland, it was about four years ago so it was actually when the referendum was just announced and I remember I was in school and somebody, like we were doing persuasive essays, and the teacher was trying to get us to discuss things, and he put up Scottish independence, and this guy [another pupil] started talking about the economy and I thought, what has this got to do with the economy? Which seems so naïve now, but for me I thought it was kinda like Ireland and I thought, got taken over by England and kinda, very kinda Braveheart-y.

(Tom)

Whilst Tom challenged his initial romanticised views, Fiona typified the critical and active stance taken by our respondents:

I did Higher Modern Studies and we got Kezia Dugdale [Scottish Labour] into our class, and they were going on about 'ah we've done this for Dundee, and we've done that for Dundee' and I was kind of thinking, hmmm I'm not too sure about you, and then they were going on about the referendum's a terrible thing, we're never gonna get it, don't vote for it, blah blah blah... and I was like, no I'm definitely, I'm not taking on anything that you're saying, and it just really annoyed me... and before they left, they asked for a show of hands, of who was gonna be voting Yes in the referendum, and I was the only person in my whole class that put my hand up.

(Fiona)

Accounts of developing more independent views were especially evident in relation to participants' parents and immediate family members, and both those who broadly agreed with 
their parents, and those who disagreed, emphasized the development of their own political opinions and allegiances. Mike, for example, recalled how:

My reasons for voting yes changed, I was brought up in a very Nationalist family, so when [the referendum] was first announced it was like, well I'm voting Yes, I think Scotland should be independent. 'Why do you think Scotland should be independent? Well it just should, was kinda like, my only argument at the start. (Mike)

As Mike's 'at the start' suggests, however, he subsequently developed his own more considered arguments for independence, which departed from his 'nationalist upbringing' and family background.

Participants narrated critical moments in their own becoming engaged, and described the facilitating role that chance encounters and significant others played in inspiring and enabling their political interest and action. When it came to immediate families however, interviewees painted a picture of themselves as becoming increasingly autonomous. This leads us to the final analytical theme, of participants' own narratives of transitioning to a relatively independent, politically engaged, adulthood.

\section{Transitions to 'Independent' Adulthood}

We begin here with Mike's account of how he 'went his own way', with his political allegiances diverging in some respects from his 'nationalist' family: 
I've always been a Yes voter, because I've been bought up in a very nationalist, SNP [household], so I've never thought anything different to an independent Scotland, but I went my own way, and done my own campaigning during the referendum, speaking to people from the Green Party, the SNP, the SSP, people from no party, and I campaigned with everybody during the referendum, and made a point that I was not going to join any party, 'til after the referendum, I'll see what the political landscape of Scotland is like, and then I'll decide, but then, but I'd been working very closely with the SSP during the referendum, and I joined them because their policies represent what I believe in (Mike)

Russell told a similar story, and described being in a broad 'ideological' agreement with his parents, but disagreeing over 'logistics of campaigning'. Whilst Mike echoed his families' proindependence views, his decision to branch out to the SSP was significant and 'caused a little bit of tension' within his family:

Aw nah they just said 'ah you should of joined the SNP, it's the way forwards, and once we get independence then we can chose parties, but you should have joined the SNP', but it's like nah, they don't fully represent what I support, when I first started campaigning I went my own way, made my own mind up, found out my own things, and done it for myself.

(Mike)

Such 'tension' however didn't seem to translate into any on-going division. Rather, and similar to other interviewees, there was a sense of agreeing to disagree. While Anne described divergent political views from both her No-voting parents, this divergence was 
framed in terms of a mature disagreement, and a respectful understanding between her parents and herself, if not between herself and her Grandma:

I would be right in there with the politics chat, with my Grandma, she'd just be like 'you don't know what you're talking about', 'you're too young to know what you're talking about' but my Mum and Dad would always stick up for me, they're like 'nah, she does know what she's talking about' like 'she thinks completely different from us but she knows what she's talking about, she probably knows a lot more what she's talking about than you do'.

(Anne)

Anne's politics are now diametrically opposed to her parents', but they defended her right to a different position and her ability to think for herself. This example of amicable 'grown up' disagreement was common:

I think a lot of the No campaign were like 'oh it's breaking families apart and all this stuff', and it's like no it's not, people are discussing things in a kind of grown-up kind of way, and that doesn't mean that they hate each other, they just disagree you know... (Russell)

Similarly Mike described political disagreements with a close friend, which were on-going and sometimes 'tiresome' but ultimately enjoyable because both liked debating and 'it was never going to break a friendship'. Finally, James described how he navigated friendship and politics: 
Aye, it caused a bit of a rift, the first thing, with my friend Mark, but we patched it up [...] he unfriended me on Facebook, and I felt a bit confused and so asked him what happened and he said he was just really pissed off with what I said, and I decided to leave it at that, until a couple of months ago, and I contacted him and said that I didn't want something as silly as politics to get between our friendship.

(James)

Not only did participants disagree with their parents and significant others, but our interviewees described how they had influenced, or attempted to influence, the political allegiances and voting habits of older family members. Gregg noted that the referendum had led him to encourage his Grandmother to vote:

She'd never voted for years, like years and years, and she was always very critical of like, wanting to see change, and like 'these politicians, what do they care?' and very, extremely apathetic, and then the referendum first came about and she says 'ach I'm no voting for that', and that pissed me off, 'cause I said to her, you know 'well I think that's ridiculous, $[\ldots]$ how can you justify not voting for years then voting to keep the system you've said is broken?' and she sort of just looked at me, and we didn't really speak about it anymore ... and then I think she just looked into it, and I think she became just like absolutely emphatic Yes.

(Gregg)

Indeed, Gregg described how his Grandmother eventually was so 'emphatically' proindependence that she opened her flat up as a canvassing base. Likewise, Fiona described successfully persuading her father, initially a 'no' to vote 'yes', and attempting to persuade her 
Grandmother to vote 'yes' too. Mike attempted to persuade his maternal Grandmother to vote 'yes', and Russell persuaded his Dad to join the Scottish Greens shortly after the vote. Our participants, therefore, were not 'copying' their parents' political views, but described a varied intergenerational influence that ran in multiple directions. Indeed, in participants' descriptions of their active decision making processes, our analysis questions whether the routinized act of voting should be accorded such importance in engagement studies.

Participants narrated their burgeoning political engagement in relation to their own emergent 'independent' adulthoods in three further senses: they developed new skills, competencies and confidences; imagined new career possibilities; and reflected on disappointments and opportunities in their own life-courses. Several respondents emphasized the public speaking skills they learnt through their referendum engagement. Sandra and Mike both organised debates at school, supported by their teachers:

My school was heavily 'No' [...] I organized a debate in my school, first time I'd ever done any public speaking, debated in front of the whole of fifth and sixth year, at the start about $70 \%$ said No, so that was kind of daunting [...] but there was a panel of judges made up of an English teacher, and Modern Studies teacher and a Physics teacher I think, and they concluded that the Yes side won the debate, so I was kinda happy with that.

(Mike)

Oh yeah, I would never be able to talk about any of this stuff before that, it helped me like with like communication as well ‘cause like, I wouldn't say I was quiet, but like I 
was maybe a bit shier with things that I am now, whereas I can like speak publically and stuff like that now ...

(Sandra)

I just kind of went up [to campaigners] myself, and my Mum's like that: 'I can't believe you went up there on your own, just to see what was going on' [...] it's made me quite sociable.

(Fiona)

For these interviewees, their politicization included 'personal' and 'biographical' changes such as overcoming shyness, learning public speaking, and building the confidence to research and form opinions. One key point to reiterate here is that these young people described themselves as initially disengaged from formal politics:

Before the referendum I wasn't that political, [...] I kinda just thought well, I'm too young to know about this, I'll leave it to the adults, it doesn't really affect me either way. (Anne)

Anne here echoes the literature and its description of young people as engaged with local issues that affect them directly, 'social things, so like small things like, going into a supermarket and having like a security guard follow you around... nothing really political'. Anne contrasted this with her current situation, standing as an SYP candidate and being inspired to study at college:

I didn't care, I honestly didn’t care [...] They [parents] don't know where it came from, they're like, 'you never used to be like this, you never used to care about politics' and 
like as soon as I told them that I was running for candidate, that I was running for MSYP [Member of the Scottish Youth Parliament] they were like 'since when? Since when do you like politics so much?' and I told them that I'm going to do social sciences at college, I applied to do that, and I applied to do it 'cause it had politics in it, and I told them that was why I wanted to do it...

(Anne)

Anne here orientates her future self towards politics in a way that is broader than voting, party membership and wider activism, to include decisions about her future education. Russell, Gregg, Brian, and Mike all spoke of their referendum engagement as inspiring or relating to their choices about what to study and their imagined future careers. Russell had recently applied for an internship at the Scottish Parliament and spoke of an on-going commitment to both charity work and campaigning for the Scottish Greens, Gregg was studying Social Policy at university, and Mike was studying Politics. Brian was committed to engaging younger people with political issues through his employment as a youth worker. Participants saw their political engagement as situated in relation to their lives as a whole:

I think you know, I think I will keep active in politics, I hope so, 'cause I just kind of feel like I'm on this planet and I'm gonna die one day, and that's a bit of a morbid thought but, not that I want to have this big lasting legacy, but I just feel like when I do die, I wanna feel like I did some kind of good in the world...

(Tom)

Russell went further, explicitly linking independence politics to his 'own independence': 
I felt slightly frustrated with school, I felt like school was great but I'd really like to be at the next thing, and I felt kind of like independence would let me [do that], kind of, it was about, I suppose my independence just as much as Scotland's.

(Russell).

Russell linked a personal wanting 'something different' for himself to the political changes he'd like to see:

I'd have really liked to have been part of independence, I dunno, to maybe even be a professional politician... I really felt like I wanted something different, for me, and then, that kind of translated into my radical politics for Scotland as well... it was just kind of a pretty deep desire for change

He went on to compare 'losing' the referendum to other disappointments of a more personal character, his decision to leave school, and reconsider his options:

Well I suppose because, it's like when you lose [the referendum] you realize what you lost if you see what I mean, but after a loss, I thought right, I have to put more effort into this, so I suppose my kind of activity went up a little bit and I joined the Greens and thought you know I have to do something about this ... and then I thought, after the result I decided not to do sixth year, I just thought, I'll go and do a year of charity work or something, and so then I looked for stuff and I found an apprenticeship at the Scottish Parliament, and that looked great, and actually I just had the interview on Thursday and I've not got it... so that's pretty bad yeah, 'cause it would have been so great, but I think and then I turned that into, I turned the kind of defeat of the referendum into a drive to 
then do something with my life [...] I think, I know, dealing with kind of things like not getting the apprenticeship, not getting the Yes vote, it's really difficult but the only way you can, or I can, deal with that is by going 'okay well what's the next thing?', 'cause, if you just sit and think 'it's so terrible that that happened', then you don't achieve anything, but if you just keep going, as long as you find out why you didn't get, you know the apprenticeship, or why Scotland didn't vote Yes, as long as you learn your lessons.

(Russell)

While respondents, rather bombastically, could claim that 'politics won't be the same again, definitely not' (Fiona) we can moderate this statement and suggest that politics won't be the same again for them: developing political engagement was bound up with personal changes, as interviewees made sense of what it means for them to 'become independent' in relation to their worlds of family, friends, school, further study and careers.

\section{Conclusion}

Whilst our findings are exploratory, we can conclude that situating young people's political participation in relation to their own understandings of their transitions to adulthood offers a fruitful contribution to the debates that characterize participation studies. For these young, first time voters, political activity was a new experience, and was narrated in contrast to their previously 'inactive' selves. The process of becoming engaged with referendum politics was facilitated by critical moments and significant others, but these remarkably active young people understood their political ideas, affiliations, and actions as increasingly autonomous. As well as 'becoming independent' from their significant others, participants learnt new skills, and presented themselves as becoming increasingly capable of 'mature' discussion and 'adult' 
disagreement, they did not let politics cause any lasting division between themselves and the people they cared about. Finally, participants drew on their referendum experience as they reflected upon, and made decisions about, transitions out of school, further study and employment, and the opportunities and disappointments such transitions offered.

The narratives presented above evoke the passion that characterised the referendum. Our respondents demonstrated a capacity for informed debate and decision-making that is the hallmark of citizenship and, significantly, they had (re)connected to formal, institutional politics as well as articulating broader interest in and engagement with 'new' forms of political participation. However, the enfranchisement of 16-17 year old Scots in the 2014 referendum was followed by their effective disenfranchisement from the 2015 UK General Election eight months later:

I've been disenfranchised, that's horrible, I got to vote in the Referendum, the most important thing ever, and now I don't get a vote in the General Election, that's pretty crap.

(Russell)

After the Referendum having engaged and inspired so many, several of our interviewees were deemed to be too young in the 2015 General Election. This pattern was repeated when 16 and 17 year olds in Scotland were eligible to vote in the Holyrood elections of May 2016, and then excluded from the June 2016 EU referendum. We therefore follow the Power Commission (2006) in calling for the voting age to be reduced to 16 across the UK. However, we also echo some respondents who were cautious in their evaluation of the longer-term impact: 
I think a lot of people think that you know the referendum like politicized a generation and all that kind of thing, but from where I'm standing, [...] I think what it's done is it's mobilized a small group of really committed people [...] I think people still think of politics as that boring thing you see on the TV, it's a change but it's not massive.

(Russell)

Such caution is instructive and important, and points to the more unique characteristics of the referendum itself, as opposed to 'that boring thing that you see on the TV'. Likewise, our findings on the close relationship, in interviewees' own understandings, of their political participation and transitions to adulthood, may prove to be a function of the specific emotional dynamics of the referendum; as participants recount their experiences in terms of learning something valuable (about themselves, adulthood, electoral politics) in the wake of 'not getting what they wanted' politically. It remains to be seen, and further work is required, to investigate whether these dynamics are also characteristic of young people voting on the 'winning' side, and among those who do not vote or whose political engagement does not include participation in parliamentary/electoral politics. As the 2016 referendum on the UK leaving the EU has shown, the importance of understanding both how young people do and do not become politicised, and generational differences in voting patterns, is only going to increase. 


\section{References}

Ballard, P. J. (2014) 'What Motivates Youth Civic Involvement?', Journal of Adolescent Research 1-25

Bang, H. P. (2009) '“Yes We Can': Identity Politics and Project Politics for a Late-Modern World', Urban Research and Practice 2(2): 117-137

Barry, M (2010) 'Youth transitions: from offending to desistance', Journal of Youth Studies, $13: 1,121-136$

BBC (2014) 'Scottish referendum: 'Yes' parties see surge in members', [online] [accessed April 2016] [Available from: http://www.bbc.co.uk/news/uk-scotland-scotland-politics29311147]

Beck, U., (1992), Risk Society: Towards a New Modernity, London: Sage.

Coles, R. 1986. The Political Life of Children. Boston: Atlantic Monthly Press.

Cunningham, S and Lavalette, M. 2004. “Active citizens' or 'irresponsible truants'? School student strikes against the war', Critical Social Policy 24(2): 255-269

Duncanson, Hilary (2015) 'Boost for SNP as membership hits 100,000 mark', The Scotsman [online] [accessed April, 2016] [available from: http:/www.scotsman.com/news/uk/boostfor-snp-as-membership-hits-100-000-mark-1-3725308] 
Eichhorn, J,. Heyer, A and Huebner, C. (2014) 'Who influences the formation of political attitudes and decisions in young people? Evidence from the referendum on Scottish independence', Edinburgh: d|part Briefing 04 March 2014.

Eichhorn, J,. Kenealy, D,. Parry, R,. Paterson, L. and Remond, A. (2015) 'Voting At 16 What Next? 16-17 Year Olds' Political Attitudes And Civic Education', Edinburgh: Academy of Government Briefing

Furlong, A and Cartmel, F. (2012) 'Social Change and Political Engagement Among Young People: Generation and the 2009/2010 British Election Survey', Parliamentary Affairs (2012) 65 (1): 13-28.

Giddens A (1991). Modernity and self-identity: Self and society in the late modern age. Cambridge: Polity Press.

Giddens A (1984). The constitution of society: Outline of the theory of structuration. Cambridge: Polity Press.

Hansard Society. 2009. Audit of Political Engagement 6: The 2009 Report. London: Hansard. Hay C (2007) Why We Hate Politics. Cambridge: Polity Press.

Henderson S; Holland J; McGrellis S; Sharpe S; Thomson R (2004) 'Inventing adulthoods: a biographical approach to understanding youth citizenship', The Sociological Review 52(2): 218-239. 
Henn, M and Foard, N. 2014. 'Social differentiation in young people's political participation: the impact of social and educational factors on youth political engagement in Britain', Journal of Youth Studies 17(3): 360-380

Henn, M., Weinstein, M. and Wring, D. (2002). ‘A generation apart? Youth and political participation in Britain', British Journal of Politics and International Relations, 4 (2), 167192.

Holland J and Thomson R (2009) 'Gaining Perspective On Choice And Fate', European Societies 11(3): 451-469.

Jones, G., (1996) 'Deferred citizenship: a coherent policy of exclusion?’ Young people now March, pp. 26-27.

Keen, R. and Audickas, L. (2016) 'Membership of UK Political Parties', House of Commons Briefing Paper Number SN05125, 5 August 2016 available from:

http://researchbriefings.files.parliament.uk/documents/SN05125/SN05125.pdf

Kennouche, Sofiane (2015) 'In numbers: Scottish political party membership', The Scotsman [online] [accessed April, 2016] [available from: http://www.scotsman.com/news/politics/innumbers-scottish-political-party-membership-1-3905167]

Kisby, B and Sloam, J. 2009. 'Revitalising Politics: The Role of Citizenship Education', 
Representation 45(3): 313-324

MacDonald, R. (1998) 'Youth, Transitions and Social Exclusion: Some Issues for Youth Research in the UK', Journal of Youth Studies 1(2): 163-176

MacDonald R and Shildrick T (2007) 'Street Corner Society: Leisure Careers, Youth (Sub)culture and Social Exclusion', Leisure Studies 26(3): 339 - 355.

Manning, N and Edwards, K. (2014) 'Why has civic education failed to increase young people's political participation? Sociological Research Online 19(1)5

Marsh, D., and Akram, S. (2015) 'Political Participation and citizen engagement: Beyond the mainstream', Policy Studies 36(6): 523-531.

Marsh, D., O'Toole, T. and Jones, S. (2007) Young People and Politics in the UK: Apathy or Alienation? Basingstoke, Palgrave.

Matthews, H,. Limb, M and Taylor, M. (1999) 'Young people's participation and representation in society', Geoforum 30(2): 135-144

Norris, P. 2011. Democratic Deficit: Critical Citizens Revisited. Cambridge: Cambridge University Press. 
Norris, P (2007) 'Political Activism: New Challenges, New Opportunities', in C. Boix and S. Stokes (eds.) The Oxford Handbook of Comparative Politics Oxford: Oxford University Press pp. 628-652

Power Commission. 2006. Power to the People: The Report of Power: An Independent Inquiry into Britain's Democracy. York: Joseph Rowntree Trust.

Putnam, R. D. (2000) Bowling Alone: The collapse and revival of American community New York: Simon \& Schuster

Rubin, B. (2007) “There's still not justice': Youth civic identity development amid distinct school and community contexts. Teachers College Record 109: 449-481

Russell, A,. Fieldhouse. E,. Purdham, K and Kalra, V. (2002) Voter Engagement and Young People, London: The Electoral Commission.

Sloam, J. 2007. 'Rebooting democracy: Youth participation in politics in the UK', Parliamentary Affairs 60(4): 548-567

Stephen, D. E. and P. A. Squires (2003) "'Adults Don't Realize How Sheltered They Are'. A Contribution to the Debate on Youth Transitions from Some Voices on the Margins." Journal of Youth Studies 6(2): 145-164.

The Electoral Commission (TEC) (2014) 'Scottish Independence Referendum Report on the referendum held on 18 September 2014' [online] [accessed April 2016] [available: 
http://www.electoralcommission.org.uk/ data/assets/pdf file/0010/179812/Scottishindependence-referendum-report.pdf]

Thomson R and Holland J (2002) 'Imagined Adulthood: Resources, plans and contradictions', Gender and Education 14(4): 337-350.

Thomson, R., Bell, R., Holland, J., Henderson, S., McGrellis, S. and Sharpe, S., (2002)

'Critical moments: choice, chance and opportunity in young people's narratives of transition'. Sociology 36(2), pp.335-354

Wyn, J. and Dwyer, P., 1999. New directions in research on youth in transition. Journal of Youth Studies, 2(1), pp.5-21. 